\title{
Species differences in lipoprotein lipase and hepatic lipase activities: comparative studies of animal models of lifestyle-related diseases
}

\author{
Norie KIMURA ${ }^{1)}$, Akio KIKUMORI ${ }^{2)}$, Daisuke KAWASE ${ }^{3)}$, Mitsumasa OKANO ${ }^{4}$, \\ Kumiko FUKAMACHI ${ }^{3)}$, Tatsuro ISHIDA ${ }^{4)}$, Katsuyuki NAKAJIMA ${ }^{5)}$ and Masashi SHIOMI SH, $^{1, \dagger, \dagger \dagger}$ \\ 1) Division of Comparative Pathophysiology, Department of Physiology and Cell Biology, Kobe University Graduate \\ School of Medicine, 7-5-1 Kusunoki-cho, Chuo-ku, Kobe, Hyogo 650-0017, Japan \\ ${ }^{2)}$ Institute for Experimental Animals, Kobe University Graduate School of Medicine, 7-5-1 Kusunoki-cho, Chuo-ku, \\ Kobe, Hyogo 650-0017, Japan \\ 3)Immuno-Biological Laboratories Co., Ltd., 3-39-15 Showa-machi, Maebashi, Gunma 371-8514, Japan \\ ${ }^{4)}$ Division of Cardiovascular Medicine, Department of Internal Medicine, Kobe University Graduate School of \\ Medicine, 7-5-1 Kusunoki-cho, Chuo-ku, Kobe, Hyogo 650-0017, Japan \\ ${ }^{5)}$ Department of Clinical Laboratory Medicine, Gunma University Graduate School of Medicine, 4-2 Aramaki-cho, \\ Maebashi, Gunma 371-8510, Japan \\ 'Present address: Division of Cardiovascular Medicine, Department of Internal Medicine, Kobe University \\ Graduate School of Medicine, 7-5-1 Kusunoki-cho, Chuo-ku, Kobe, Hyogo 650-0017, Japan \\ tPresent address: Devision of Biological Resources and Development, Analytical Research Center for Experimental \\ Sciences, Saga University, 5-1-1 Nabeshima, Saga 849-8501, Japan
}

\begin{abstract}
Lipoprotein lipase (LPL) and hepatic triglyceride lipase (HTGL) have an important role in lifestyle-related diseases. To evaluate species differences, we compared LPL and HTGL activities in different animal models of lifestyle-related diseases using the same assay kit. Normal animals (JW rabbits, ICR mice, and SD rats), a hypercholesterolemic animal model (WHHLMI rabbits), and obese animal models (KK- $A^{y}$ mice and Zucker fatty rats) fed standard chow were used in this study. Plasma was prepared before and after an intravenous injection of heparin sodium under fasting and feeding. LPL and HTGL activities were measured with the LPL/HTGL activity assay kit (Immuno-Biological Laboratories) using an auto-analyzer. Only in mice, high HTGL activity was observed in pre-heparin plasma. In normal animals, LPL and HTGL activities were high in ICR mice and SD rats but low in JW rabbits. Compared to normal animals, LPL activity was high in Zucker fatty rats and WHHLMI rabbits at both fasting and feeding, while LPL activity after feeding was low in KK- $A^{y}$ mice. HTGL activity was higher in fasted and fed WHHLMI rabbits and fasted Zucker fatty rats, but was lower in fed KK-Ay mice. Gender difference was observed in HTGL activity in SD rats and LPL activity in WHHLMI rabbits but not in ICR mice. In conclusion, this simple assay method was effective for measuring LPL and HTGL activities of experimental animals, and the activities are highly regulated depending on animal species, animal models, feeding/fasting conditions and genders.

Key words: animal model, hepatic triglyceride lipase (HTGL), lipoprotein lipase (LPL), species difference
\end{abstract}




\section{Introduction}

Lipoprotein lipase (LPL) and hepatic triglyceride lipase (HTGL) are key enzymes involved in lifestyle-related diseases, such as obesity [33], metabolic syndrome [33], dyslipidemia [7], and atherosclerosis [28]. These lipases mediate the decomposition of triglycerides in chylomicron (CM), very low density lipoprotein (VLDL), and intermediate density lipoprotein (IDL) particles [21], and are involved in receptor-mediated VLDL catabolism $[17,23,34]$. Overexpressing human LPL suppressed atherosclerotic lesions in LDL receptor-deficient mice [31], and HTGL-deficiency delayed the development of atherosclerosis in SR-BI/apolipoprotein E double knockout mice [12]. In contrast, atherosclerotic lesions were enhanced in transgenic rabbits overexpressing human LPL $[9,15]$ or HTGL [35]. It is necessary to consider the influence of the expression site of the introduced gene, but all involvement of LPL and HTGL in atherosclerosis has not been elucidated. Active and inactive HTGL are present in post-heparin plasma [22], and catalytically inactive LPL is present in transgenic mice [24]. In addition, normal LPL activity is observed in post-heparin plasma in some patients with hyperlipidemia because of apoC-II deficiency [13]. These observations suggest importance of measuring the activity of LPL and HTGL, in addition to the expression of LPL and HTGL genes or proteins. However, conventional activity methods are time-consuming, and the use of radioactive isotopes is required. Imamura et al. [10] developed a simple method to measure the activity of LPL/HTGL that does not use radioisotopes. Recently, Nakajima et al. [27] improved Imamura's method for the clinical laboratory by developing a simple and accurate automated assay. If this simple assay method can be used to measure the LPL and HTGL activities of laboratory animals, studies of lifestyle-related diseases using animal models can be promoted. In this study, we examined the practicality of the newly developed assay method for LPL and HTGL activities in different animal species and different animal models of lifestyle-related diseases, and examined species differences in LPL and HTGL activities. Although LPL and HTGL activities were measured in several animals species, species difference of these lipase activity have not been examined using the same assay method. To examine the species difference, LPL and HTGL activities in different laboratory animals and animal models of lifestyle-related dis- eases (KK- $A^{y}$ mice, Zucker fatty rats, and WHHLMI rabbits) were compared using the same assay method [27]. The KK- $A^{y}$ mouse is a polygenic animal model for obesity and hyperinsulinemia because of increased degranulation of $\beta$-cells and hypertrophy of pancreatic islet cells [11]. The Zucker fatty rat is a polygenic animal model for obese and hyperinsulinemia because of hyperphagia and energy expenditure from impaired leptin signaling resulting by the $f a$ mutation in the leptin receptor [30]. The WHHLMI rabbit is an animal model for coronary atherosclerosis and hypercholesterolemia because of LDL receptor deficiency [32].

\section{Materials and Methods}

\section{Animals}

We used ICR mice (Jcl:ICR, 5 weeks old, 6 females and 6 males), KK- $A^{y}$ mice (KK- $A^{y} / \mathrm{TaJcl}, 5$ weeks old, 20 females), SD rats (Slc:SD, 5 weeks old, 6 females and 6 males), Zucker fatty rats (Slc:Zucker- $f a / f a, 5$ weeks old, 20 females), Japanese white (JW) rabbits (Kbl:JW, 4 months old, 6 males), and WHHLMI rabbits (6 months old, 6 females and 6 males). ICR and KK- $A^{y}$ mice were purchased from CLEA Japan, Inc. (Tokyo, Japan), SD and Zucker fatty rats were purchased from Japan SLC, Inc. (Hamamatsu, Japan), JW rabbits were purchased from Kitayama LABES, Co., Ltd. (Ina, Japan), and WHHLMI rabbits were bred at the Institute for Experimental Animals, Kobe University Graduate School of Medicine (Kobe, Japan). In lipoprotein analyses, blood samples $(500 \mu 1)$ were obtained before and 5 or 15 min after heparin injection in each animal. In an assay of lipase activity, heparin was injected intravenously in the subclavian vein for mice and rats under light anesthesia with isoflurane or in the marginal ear vein for rabbits at a dose of 100 units $/ \mathrm{kg}$. Blood samples $(100 \mu \mathrm{l})$ were collected from the subclavian vein or orbital venous plexus of mice under light anesthesia with isoflurane before and after heparin injection $(5,15,30$, and $60 \mathrm{~min}$ ), and from the tail vein or subclavian vein of rats under light anesthesia with isoflurane before and after heparin injection $(15,30,60$, and $120 \mathrm{~min})$. Mice and rats were euthanized after blood collection with excessive anesthesia without awakening. In rabbits, a 1-ml blood sample was collected from the marginal ear vein before and after the heparin injection $(15,30,60$, and $120 \mathrm{~min}$ ). Experiments were conducted after more than $12 \mathrm{~h}$ fasting and $2 \mathrm{~h}$ after feeding. Plasma was stored 
at $-80^{\circ} \mathrm{C}$ until analysis. Animals were maintained under SPF conditions with a constant temperature $\left(22 \pm 2^{\circ} \mathrm{C}\right)$, relative humidity $(50-60 \%)$, ventilation rate $(15$ cycles/h), air supply (through a HEPA filter), and 12-h light/dark cycle. Animals were fed standard chow [CE2 (CLEA Japan, Inc.) for mice and rats ad libitum, and LRC4 (Oriental Yeast Co., Ltd., Tokyo, Japan) for rabbits $120 \mathrm{~g} /$ day].

This study was approved by the Kobe University Animal Care and Use Committee (approval numbers: $\mathrm{P} 180201, \mathrm{P} 180202$, and P180204), and all animal experiments and care of animals were conducted in accordance with the Regulations for Animal Experimentation of Kobe University, the Act on Welfare and Management of Animals (Law No. 105, 1973, revised in 2006), Standards Relating to the Care and Management of Laboratory Animals and Relief of Pain (Notification No. 88, 2006), and Fundamental Guidelines for the Proper Conduct of Animal Experiments and Related Activities in Academic Research Institutions under the Jurisdiction of the Ministry of Education, Culture, Sports, Science and Technology (Notice No. 71, 2006).

\section{Evaluation of LPL and HTGL activities}

LPL and HTGL activities were measured with the LPL / HTGL activity assay kit (Immuno-Biological Laboratories, Fujioka, Japan) using an auto-analyzer (BIOLIS 24i Premium, Tokyo Boeki Medisys Inc., Tokyo, Japan) according to the method reported by Nakajima et al. [26]. In brief, the LPL and HTGL activities were separately assayed using post-heparin plasma with apoC-II and without apoC-II. ApoC-II is a cofactor required for LPL activity [8]. LPL activity was calculated from total lipase activity with apoC-II by subtracting the HTGL activity measured under the same procedure without apoC-II. Since lipase activity peaked 5 min after heparin injection in mice, and became a plateau at 5-20 min after heparin injection in rats and rabbits. (Supplementary Fig. 1), lipase activities were defined as activities 5 min after heparin injection in mice, and activities 15 min after heparin injection in rats and rabbits. This assay system was available in various laboratory animals. The coefficient of variation (CV) was less than $4 \%$ (Supplementary Table 1), and the influence of repeated freezing and thawing of plasma (Supplementary Table 2) and the influence of dilution of plasma (Supplementary Fig. 2 and Supplementary Table 3) on measurement of LPL and HTGL activities were negligible in each animal species. In dilution experiment, HTGL activity showed linearity between 16 and 1557 U/1, LPL activity showed linearity between 31 and 1,146 U/1. The activity of LPL and HTGL of mice, rats, and rabbits was comparable to previous studies using radioisotopes (Supplementary Table 4) [3, 4, 25, 29, 36]. There was a strong correlation between the mass and activity of LPL and HTGL [10]. In the present study, LPL and HTGL activities were compared under several conditions; i.e. between animal species, between normal animals and animal models, fasting or feeding conditions, and gender differences.

\section{Fractionation of lipoproteins}

In KK- $A^{y}$ mice, Zucker fatty rats, and WHHLMI rabbits, lipoproteins were fractionated by HPLC at Skylight Biotech Inc. (Akita, Japan) and cholesterol and triglyceride levels were enzymatically measured.

\section{Statistical analysis}

Data were represented as the mean \pm SEM for variations in mean values or as the mean $\pm \mathrm{SD}$ for variations in measured values. Statistical analyses for differences in mean values were performed using the Student's $t$-test, Welch's $t$-test, or paired $t$-test. $P$-values less than 0.05 were considered significant. For the correlation coefficient, Pearson's correlation coefficient was calculated.

\section{Results}

\section{LPL and HTGL activities in each animal species}

As shown in Fig. 1, both normal and obese mice (fasted female) exhibited high HTGL activity in preheparin plasma $(145 \pm 29$ and $236 \pm 12 \mathrm{U} / 1$, respectively). Similar results were obtained for male mice (data not shown). In fasted female rats and male rabbits, HTGL activities in pre-heparin plasma were less than $20 \mathrm{U} / 1$. Similar results were obtained for male rats and female rabbits (data not shown). In post-heparin plasma of ICR and KK- $A^{y}$ mice and JW rabbits, LPL activity was higher than HTGL activity, while this was opposite in SD and Zucker fatty rats. There were no differences in WHHLMI rabbits between LPL and HTGL activities. Gender differences were observed in HTGL activity in SD rats and LPL activity in WHHLMI rabbits (Table 1). LPL and HTGL activities increased after feeding in ICR mice and SD rats, but not in WHHLMI rabbits (Fig. 2). 

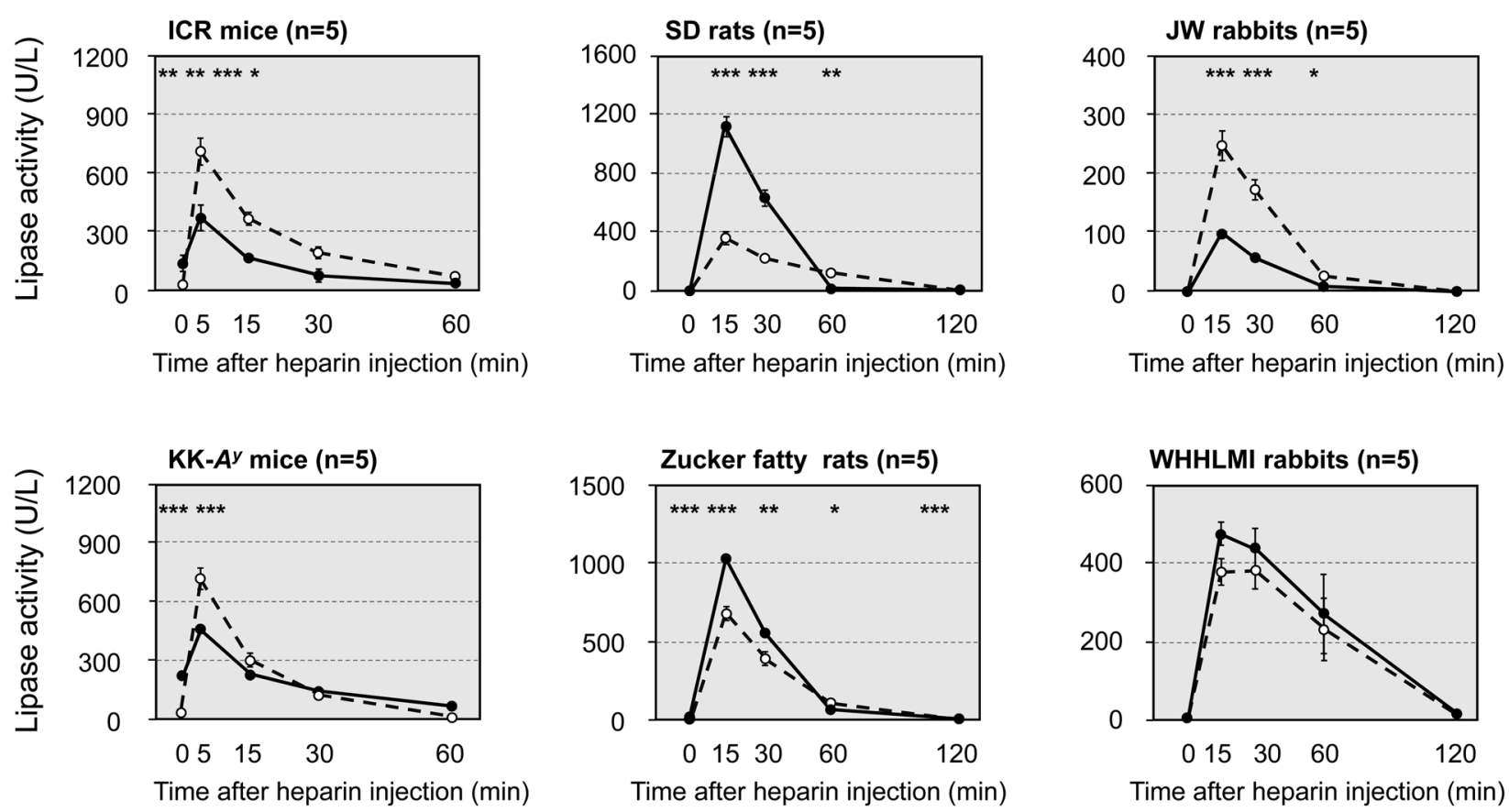

Fig. 1. Changes in lipoprotein lipase (LPL) (open circles) and hepatic triglyceride lipase (HTGL) (solid circles) activities after heparin intravenous injection in various animals. The animals used were female mice and rats, and male rabbits. Data are mean \pm SEM. Statistical analyses between LPL and HTGL activities were performed by the Student's $t$-test $\left({ }^{*} P<0.05 ; * * P<0.01 ; * * * P<0.001\right)$.

Table 1. Gender differences in lipoprotein lipase (LPL) and hepatic triglyceride lipase (HTGL) activities in various animals

\begin{tabular}{|c|c|c|c|c|c|c|c|c|c|}
\hline & \multicolumn{3}{|c|}{ ICR mouse } & \multicolumn{3}{|c|}{ SD rat } & \multicolumn{3}{|c|}{ WHHLMI rabbit } \\
\hline & $\begin{array}{c}\text { Female } \\
(\mathrm{n}=5)\end{array}$ & $\begin{array}{l}\text { Male } \\
(\mathrm{n}=5)\end{array}$ & $P$-value & $\begin{array}{c}\text { Female } \\
(n=5)\end{array}$ & $\begin{array}{l}\text { Male } \\
(\mathrm{n}=5)\end{array}$ & $P$-value & $\begin{array}{c}\text { Female } \\
(\mathrm{n}=5)\end{array}$ & $\begin{array}{l}\text { Male } \\
(\mathrm{n}=5)\end{array}$ & $P$-value \\
\hline \multicolumn{10}{|c|}{ LPL activity (U/1) } \\
\hline \multicolumn{10}{|c|}{ Pre-heparin injection } \\
\hline Fasting & $11 \pm 4$ & $21 \pm 2$ & 0.049 & $1 \pm 2$ & $-1 \pm 1$ & 0.499 & $6 \pm 3$ & $0 \pm 0$ & 0.152 \\
\hline Feeding & $18 \pm 3$ & $21 \pm 3$ & 0.500 & $6 \pm 1$ & $5 \pm 1$ & 0.801 & $0.4 \pm 0.4$ & $0.4 \pm 0.4$ & 1.000 \\
\hline \multicolumn{10}{|c|}{ Post-heparin plasma } \\
\hline Fasting & $717 \pm 67$ & $839 \pm 179$ & 0.570 & $360 \pm 44$ & $225 \pm 51$ & 0.073 & $601 \pm 78$ & $376 \pm 35$ & 0.024 \\
\hline Feeding & $1362 \pm 102$ & $1530 \pm 89$ & 0.243 & $629 \pm 48$ & $527 \pm 50$ & 0.180 & $491 \pm 33$ & $466 \pm 49$ & 0.926 \\
\hline \multicolumn{10}{|c|}{ HTGL activity (U/1) } \\
\hline \multicolumn{10}{|c|}{ Pre-heparin injection } \\
\hline Fasting & $145 \pm 29$ & $270 \pm 44$ & 0.051 & $4 \pm 1$ & $1 \pm 1$ & 0.044 & $1 \pm 1$ & $2 \pm 2$ & 0.667 \\
\hline Feeding & $263 \pm 16$ & $277 \pm 22$ & 0.610 & $20 \pm 2$ & $9 \pm 1$ & $<0.001$ & $2 \pm 2$ & $3 \pm 3$ & 0.822 \\
\hline \multicolumn{10}{|c|}{ Post heparin plasma } \\
\hline Fasting & $384 \pm 63$ & $560 \pm 89$ & 0.156 & $1121 \pm 66$ & $473 \pm 57$ & $<0.001$ & $543 \pm 64$ & $466 \pm 30$ & 0.307 \\
\hline Feeding & $847 \pm 50$ & $1017 \pm 69$ & 0.073 & $1496 \pm 85$ & $1010 \pm 154$ & 0.029 & $491 \pm 33$ & $566 \pm 64$ & 0.333 \\
\hline
\end{tabular}

Post-heparin plasma was obtained $5 \mathrm{~min}$ (mice) or $15 \mathrm{~min}$ (rats and rabbits) after heparin intravenous injection. Data are mean $\pm \mathrm{SEM}$. Statistical analyses between females and males were performed with the Student's $t$-test.

Comparison of lipase activity between spontaneous animal models of obesity or hypercholesterolemia and normal animals

Figure 3 shows the lipase activities in post-heparin plasma of normal animals and spontaneous animal models of obesity or hypercholesterolemia. LPL and HTGL activities during feeding were lower in KK- $A^{y}$ mice than in ICR mice, despite no differences in lipase activities at fasting between both strains. In KK- $A^{y}$ mice, HTGL activity was significantly elevated by feeding ( $464 \pm 26$ $\mathrm{U} / 1$ to $676 \pm 32 \mathrm{U} / 1, P<0.001$ ), but LPL activity showed no significant change. After feeding, LPL activity was 

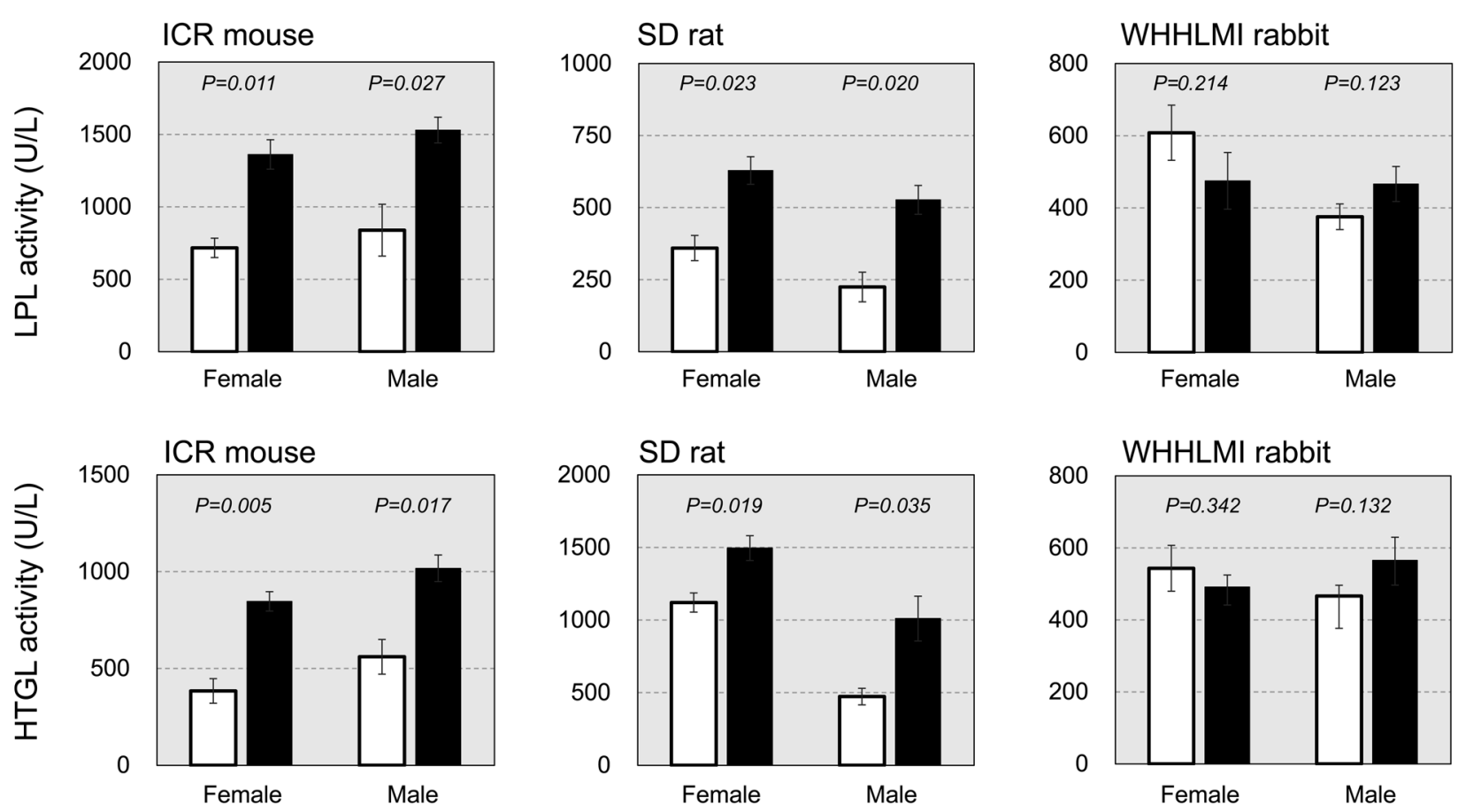

Fig. 2. Lipoprotein lipase (LPL) and hepatic triglyceride lipase (HTGL) activities in each animal species at fasting (open bars) and feeding (solid bars). Lipase activities were measured using plasma obtained 5 min (mice) or 15 (rats and rabbits) min after heparin intravenous injection. Data are mean \pm SEM. Statistical analyses between fasting and feeding were performed by Paired $t$-test.
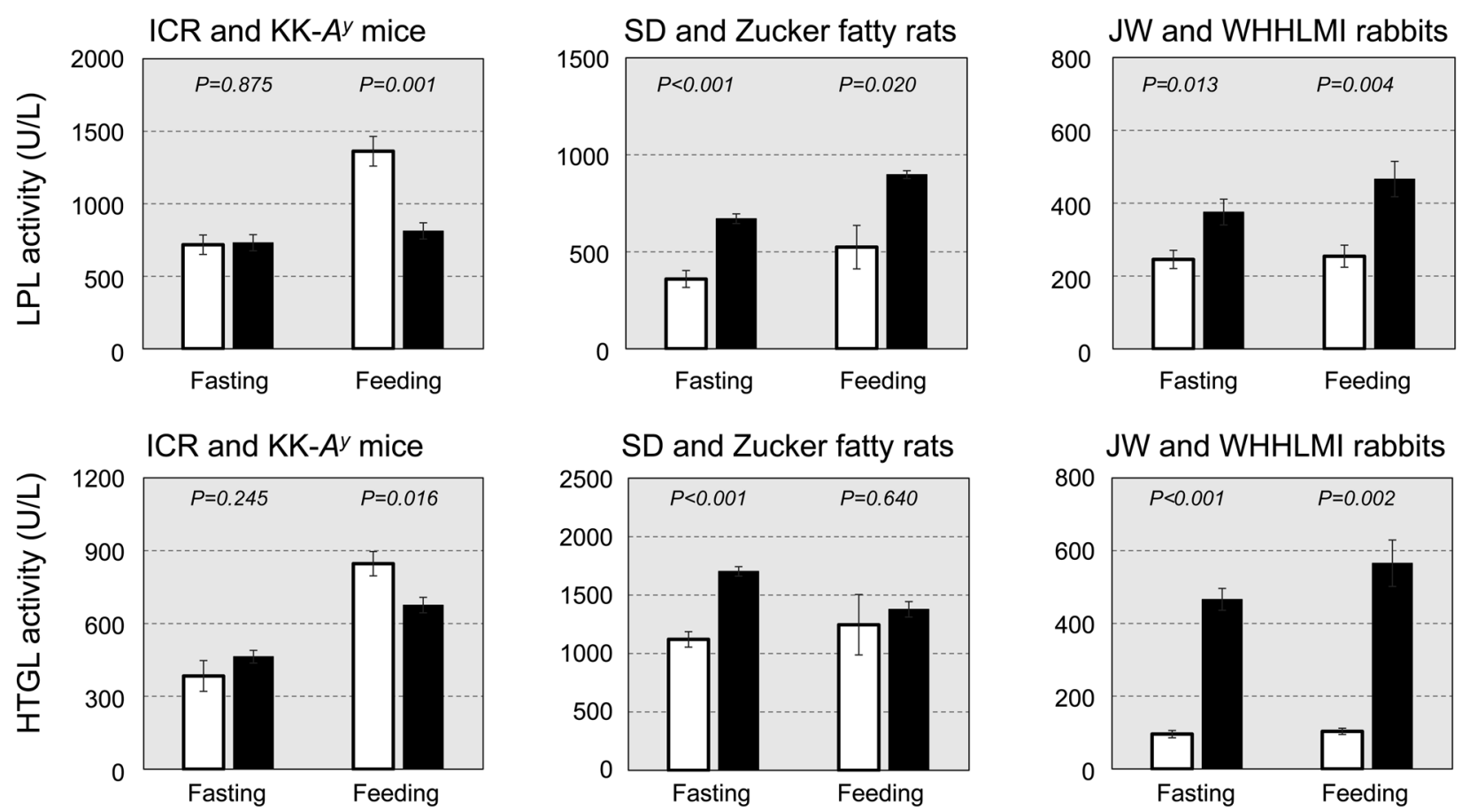

Fig. 3. Lipoprotein lipase (LPL) and hepatic triglyceride lipase (HTGL) activities in normal (open bars) and mutant (solid bars) animals. Lipase activities were measured using plasma obtained $5 \mathrm{~min}$ (mice) or $15 \mathrm{~min}$ (rats and rabbits) after heparin intravenous injection. Animals used in this experiment are females in mice and rats, and males in rabbits. Data are mean \pm SEM. Statistical analyses between normal and mutant animals were performed by the Student's $t$-test. 

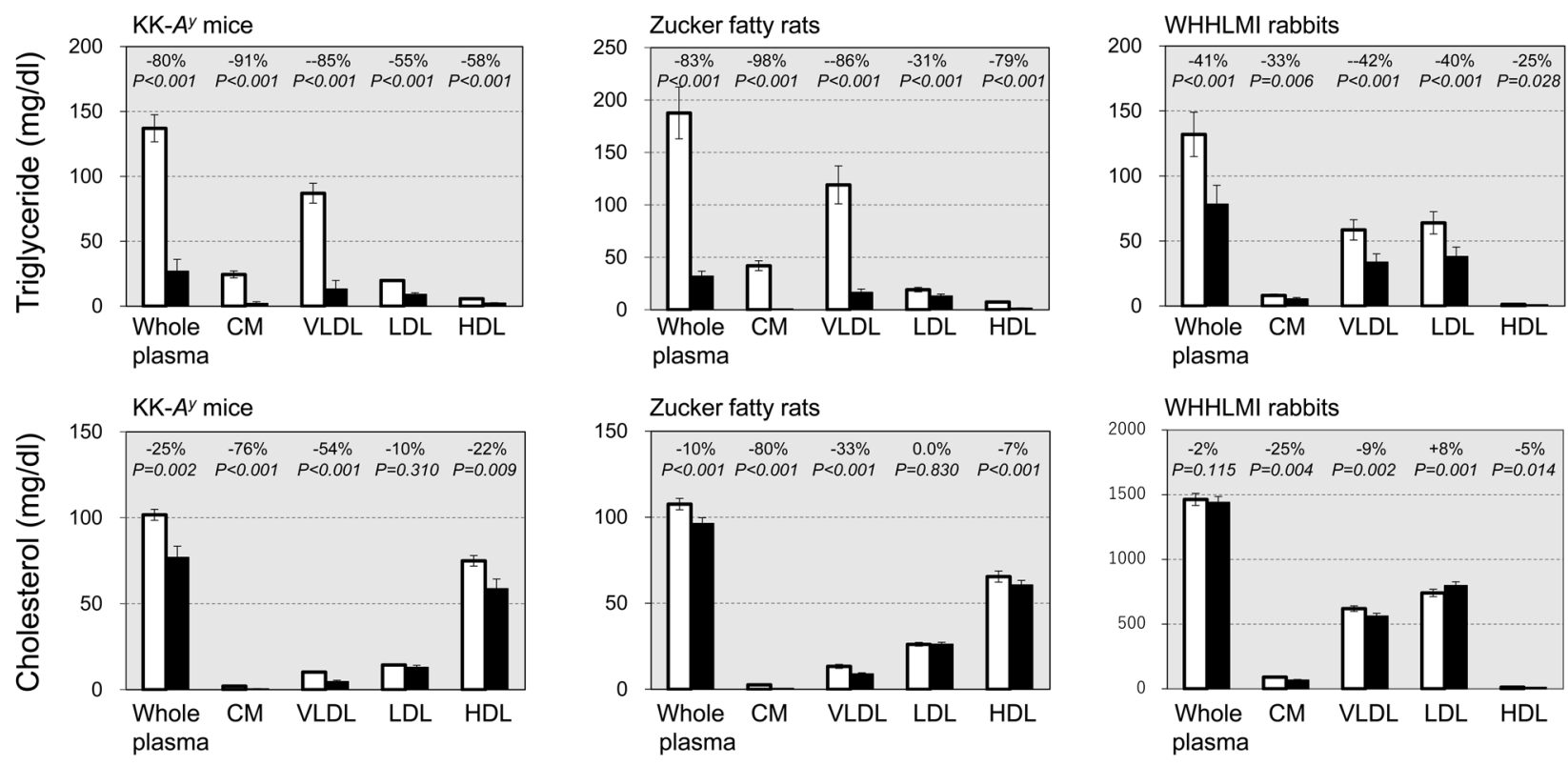

Fig. 4. Lipoprotein triglyceride levels before (open bars) and after (solid bars) heparin injection. Post-heparin plasma was obtained 5 (mice) or 15 (rats and rabbits) min after heparin intravenous injection. Lipoproteins were fractionated by HPLC (Skylight Biotech Inc.) The numerical values are the rates of change before heparin injection. Data are mean \pm SEM. Statistical analyses before and after the heparin injection were performed with a paired $t$-test.

increased in normal ICR mice despite no changes in KK- $A^{y}$ mice. LPL activity at fasting and feeding was higher in Zucker fatty rats than in normal SD rats. HTGL activity at fasting was higher in Zucker fatty rats than in normal SD rats, whereas no significant differences were observed at feeding. In Zucker fatty rats after feeding, LPL activity increased $(671 \pm 25 \mathrm{U} / 1$ to $898 \pm 20 \mathrm{U} / \mathrm{l}$, $P=0.002)$, but HTGL activity decreased $(1,703 \pm 40 \mathrm{U} / 1$ to $1,378 \pm 67 \mathrm{U} / 1, P=0.012$ ). This change in HTGL activity in Zucker fatty rats was different from normal ICR mice. LPL and HTGL activities at fasting and feeding were higher in WHHLMI rabbits than in JW rabbits. There was no difference in changes in LPL and HTGL activities by feeding between WHHLMI rabbits and normal JW rabbits. In normal animals, LPL and HTGL activities were lower in JW rabbits than ICR mice and SD rats.

\section{Changes in lipoprotein lipid levels after heparin injection}

As shown in Fig. 4, triglyceride levels in whole plasma and every lipoprotein fraction significantly decreased after heparin injection (5 min in mice and $15 \mathrm{~min}$ in rats and rabbits). In KK- $A^{y}$ mice and Zucker fatty rats, triglyceride levels in whole plasma and the CM and VLDL fractions decreased by more than $80 \%$. Cholesterol levels in whole plasma and the CM, VLDL, and HDL fractions also significantly decreased in mice and rats, whereas these decreases were smaller in WHHLMI rabbits.

\section{Relationship between lipase activity and rate of lipoprotein triglyceride reductions}

As shown in Fig. 5, LPL and HTGL activities in postheparin plasma were both strongly correlated with triglyceride levels in whole plasma and CM, VLDL, and LDL fractions in WHHLMI rabbits. Correlation coefficients were higher than 0.700 . However, a correlation was only observed between HTGL activity and LDL triglyceride levels in Zucker fatty rats, but no correlation occurred between lipase activities and lipoprotein lipid levels in KK- $A^{y}$ mice (data not shown). Lipoprotein cholesterol levels did not correlate with lipase activities (data not shown).

\section{Discussion}

In the present study, we showed that LPL and HTGL activities varied depending on the animal species, spontaneous animal models for lifestyle-related disease, fasting and feeding conditions, and gender differences in addition to the practicality of a newly developed assay 

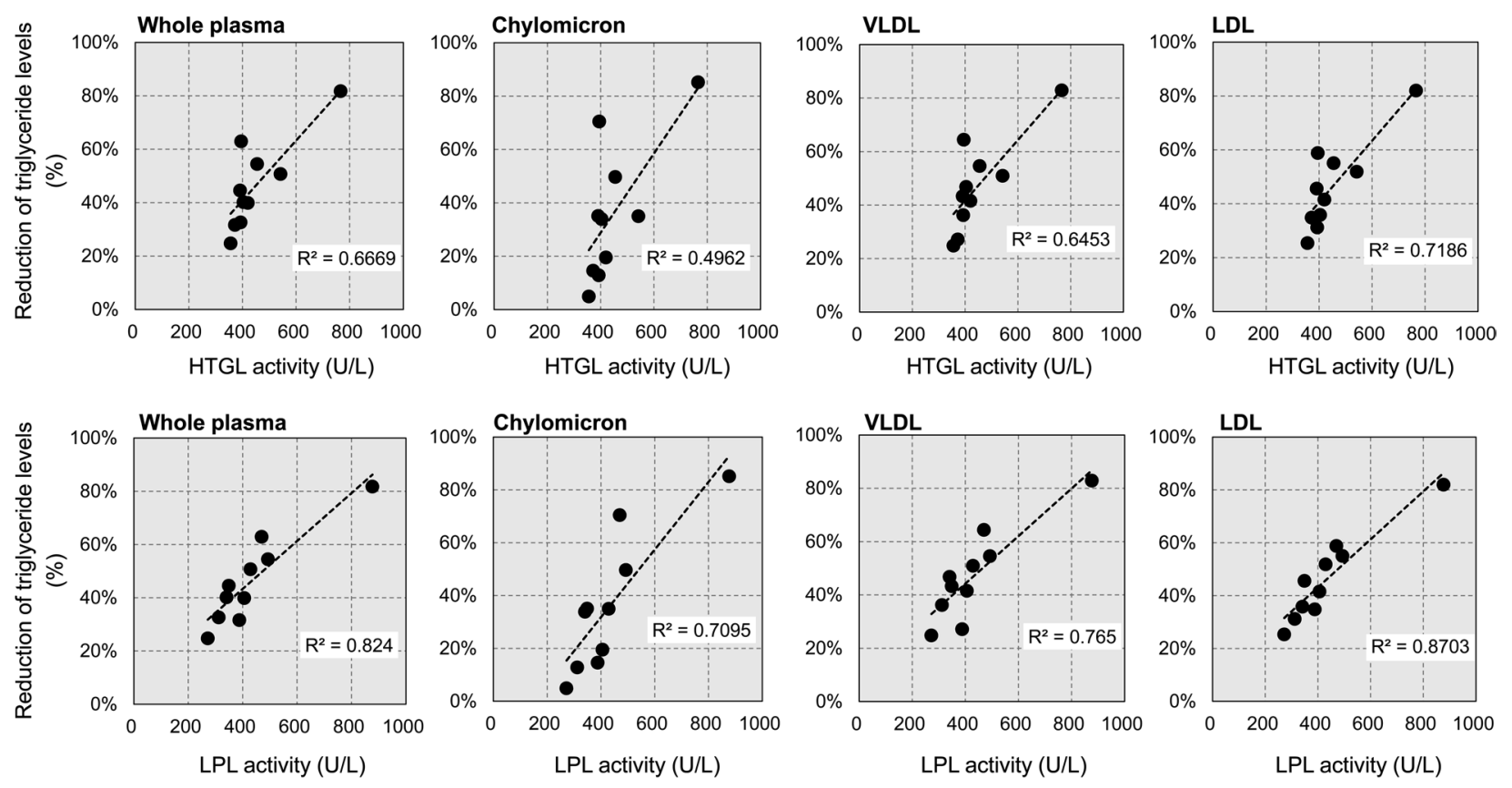

Fig. 5. Relationship between lipase activity and rates of lipoprotein triglyceride reductions in WHHLMI rabbits. $\mathrm{R}^{2}$, correlation coefficient.

method.

In normal male animals after feeding, LPL and HTGL activities were lower in JW rabbits than ICR mice and SD rats (Supplementary Table 4). In human healthy volunteers assayed using the same kit as this study, the LPL activity was $150 \pm 12 \mathrm{U} / 1$ and HTGL activity was $385 \pm$ $44 \mathrm{U} / 1$, respectively [27]. LPL and HTGL activities of mice and HTGL activity of rats were extremely high compared to human healthy volunteers.

In hypercholesterolemic WHHLMI rabbits, LPL and HTGL activities were higher than normal JW rabbits, similar to patients with human familial hypercholesterolemia [2]. In comparison between normal and obese animals, lipase activities were higher in obese animal models than in normal animals. In humans, HTGL activity negatively correlated with insulin clearance rate [18], but was positively correlated with visceral fat content, obesity, insulin resistance, and diabetes [1]. The present results of obese animal models were consistent with humans. However, KK- $A^{y}$ mice and Zucker fatty rats showed different findings. Although KK- $A^{y}$ mice and Zucker fatty rats are animal models for obese and hyperinsulinemia $[11,30]$, the cause of obesity is hypertrophy of pancreatic islet cells and degranulation of beta cells in KK- $A^{y}$ mice [11] and hyperphagia due to $f a$ mutation of leptin receptor in Zucker fatty rats [30]. These differences may be related to differences in plas- ma lipase activities of the two animal models.

Changes in LPL and HTGL activities after feeding varied among animal species. The LPL and HTGL activities after feeding were increased in ICR mice, KK- $A^{y}$ mice, and SD rats. In Zucker fatty rats, LPL activity was increased but HTGL activity was decreased after feeding. No significant changes were observed in JW and WHHLMI rabbits. In healthy young volunteers, there were no differences in plasma LPL and HTGL activities between plasma at fasting and two $h$ after meal [26]. These results suggest that the presence or absence of obesity may be related to postprandial LPL and HTGL activities.

In contrast to other animal species, high HTGL activity was observed in pre-heparin plasma of mice, which is consistent with previous findings [29]. High HTGL activity in pre-heparin plasma in mice was attributed to its low affinity for the heparan sulfate proteoglycans of liver endothelial cells [19]. In rats, HTGL activity was higher in females than in males, as reported previously [6]. However, no gender differences were observed in HTGL activity in Wistar rats. In humans, HTGL activity was higher in males than in pre-menopausal females, although there was no differences in LPL activities [1]. Visceral fat accumulation and sex steroid hormone could be related to gender difference in HTGL activities [1].

Transient decreases in triglyceride levels in each lipoprotein fraction in post-heparin plasma were promi- 
nent in KK- $A^{y}$ mice and Zucker fatty rats. Cholesterol levels in the CM and VLDL fractions in KK- $A^{y}$ mice and Zucker fatty rats also decreased after heparin infusion. These observations were consistent with previous findings of apoE-deficient mice [37]. The marked decreases in the CM and VLDL fractions observed in mice and rats are considered due to the faster receptor-mediated clearance of LPL-bound apoB-containing lipoproteins [20, 37]. It may be related to the expression of apoB-editing enzyme in the liver in mice and rats [5]. However, in WHHLMI rabbits, decreases in triglyceride levels in these lipoproteins were relatively mild, and cholesterol decreases in these fractions were small. Since apoBediting enzyme is not expressed in the liver of WHHL rabbits [16], the most VLDL particles are converted to LDL particles [14]. Furthermore, the correlations between post-heparin lipase activities and the rates of lipoprotein lipid reductions were strong in WHHLMI rabbits, but weak in mice and rats. This difference may also be caused by marked decreases in triglyceride levels in the CM and VLDL fractions in the post-heparin plasma of mice and rats as shown in Fig. 4.

\section{Conclusions}

We measured LPL and HTGL activities in various laboratory animals, and found that LPL and HTGL activities varied greatly depending on animal species, animal models, feeding or fasting conditions, and genders. The understanding of the regulated expression in vivo may help to expand our knowledge regarding the clinical relevance of these lipase activities in human diseases.

\section{Conflict of Interest}

The authors do not have any conflicts of interest to declare with respect to this manuscript.

This study was conducted using a research budget with no restrictions on research purposes.

\section{References}

1. Carr, M.C., Hokanson, J.E., Zambon, A., Deeb, S.S., Barrett, P.H.R., Purnell, J.Q. and Brunzell, J.D. 2001. The contribution of intraabdominal fat to gender differences in hepatic lipase activity and low/high density lipoprotein heterogeneity. J. Clin. Endocrinol. Metab. 86: 2831-2837. [Medline]

2. Dugi, K.A., Feuerstein, I.M., Hill, S., Shih, J., SantamarinaFojo, S., Brewer, H.B. Jr. and Hoeg, J.M. 1997. Lipoprotein lipase correlates positively and hepatic lipase inversely with calcific atherosclerosis in homozygous familial hypercholesterolemia. Arterioscler. Thromb. Vasc. Biol. 17: 354-364. [Medline] [CrossRef]

3. Fan, J., Unoki, H., Kojima, N., Sun, H., Shimoyamada, H., Deng, H., Okazaki, M., Shikama, H., Yamada, N. and Watanabe, T. 2001. Overexpression of lipoprotein lipase in transgenic rabbits inhibits diet-induced hypercholesterolemia and atherosclerosis. J. Biol. Chem. 276: 40071-40079. [Medline] [CrossRef]

4. Fan, J., Wang, J., Bensadoun, A., Lauer, S.J., Dang, Q., Mahley, R.W. and Taylor, J.M. 1994. Overexpression of hepatic lipase in transgenic rabbits leads to a marked reduction of plasma high density lipoproteins and intermediate density lipoproteins. Proc. Natl. Acad. Sci. USA 91: 8724-8728. [Medline] [CrossRef]

5. Funahashi, T., Giannoni, F., DePaoli, A.M., Skarosi, S.F. and Davidson, N.O. 1995. Tissue-specific, developmental and nutritional regulation of the gene encoding the catalytic subunit of the rat apolipoprotein B mRNA editing enzyme: functional role in the modulation of apoB mRNA editing. $J$. Lipid Res. 36: 414-428. [Medline]

6. Galan, X., Llobera, M. and Ramírez, I. 1994. Lipoprotein lipase and hepatic lipase in Wistar and Sprague-Dawley rat tissues. Differences in the effects of gender and fasting. Lipids 29: 333-336. [Medline] [CrossRef]

7. Garg, A., and Simha, V. 2007. Update on dyslipidemia. $J$. Clin. Endocrinol. Metab. 92: 1581-1589. [Medline] [CrossRef]

8. Goldberg, I.J. 1996. Lipoprotein lipase and lipolysis: central roles in lipoprotein metabolism and atherogenesis. J. Lipid Res. 37: 693-707. [Medline]

9. Ichikawa, T., Kitajima, S., Liang, J., Koike, T., Wang, X., Sun, H., Okazaki, M., Morimoto, M., Shikama, H., Watanabe, T., Yamada, N. and Fan, J. 2004. Overexpression of lipoprotein lipase in transgenic rabbits leads to increased small dense LDL in plasma and promotes atherosclerosis. Lab. Invest. 84: 715-726. [Medline] [CrossRef]

10. Imamura, S., Kobayashi, J., Nakajima, K., Sakasegawa, S., Nohara, A., Noguchi, T., Kawashiri, M.A., Inazu, A., Deeb, S.S., Mabuchi, H. and Brunzell, J.D. 2008. A novel method for measuring human lipoprotein lipase and hepatic lipase activities in postheparin plasma. J. Lipid Res. 49: 14311437. [Medline] [CrossRef]

11. Iwatsuka, H., Shino, A. and Suzuoki, Z. 1970. General survey of diabetic features of yellow KK mice. Endocrinol. Jpn. 17: 23-35. [Medline] [CrossRef]

12. Karackattu, S.L., Trigatti, B. and Krieger, M. 2006. Hepatic lipase deficiency delays atherosclerosis, myocardial infarction, and cardiac dysfunction and extends lifespan in SRBI/apolipoprotein E double knockout mice. Arterioscler. Thromb. Vasc. Biol. 26: 548-554. [Medline] [CrossRef]

13. Kei, A.A., Filippatos, T.D., Tsimihodimos, V. and Elisaf, M.S. 2012. A review of the role of apolipoprotein C-II in lipoprotein metabolism and cardiovascular disease. Metabolism 61: 906-921. [Medline] [CrossRef]

14. Kita, T., Brown, M.S., Bilheimer, D.W. and Goldstein, J.L. 1982. Delayed clearance of very low density and interme- 
diate density lipoproteins with enhanced conversion to low density lipoprotein in WHHL rabbits. Proc. Natl. Acad. Sci. USA 79: 5693-5697. [Medline] [CrossRef]

15. Koike, T., Liang, J., Wang, X., Ichikawa, T., Shiomi, M., Sun, H., Watanabe, T., Liu, G. and Fan, J. 2005. Enhanced aortic atherosclerosis in transgenic Watanabe heritable hyperlipidemic rabbits expressing lipoprotein lipase. Cardiovasc. Res. 65: 524-534. [Medline] [CrossRef]

16. Kozarsky, K.F., Bonen, D.K., Giannoni, F., Funahashi, T., Wilson, J.M. and Davidson, N.O. 1996. Hepatic expression of the catalytic subunit of the apolipoprotein B mRNA editing enzyme (apobec-1) ameliorates hypercholesterolemia in LDL receptor-deficient rabbits. Hum. Gene Ther. 7: 943957. [Medline] [CrossRef]

17. Krapp, A., Ahle, S., Kersting, S., Hua, Y., Kneser, K., Nielsen, M., Gliemann, J. and Beisiegel, U. 1996. Hepatic lipase mediates the uptake of chylomicrons and beta-VLDL into cells via the LDL receptor-related protein (LRP). J. Lipid Res. 37: 926-936. [Medline]

18. Labadzhyan, A., Cui, J., Péterfy, M., Guo, X., Chen, Y.I., Hsueh, W.A., Rotter, J.I. and Goodarzi, M.O. 2016. Insulin Clearance Is Associated with Hepatic Lipase Activity and Lipid and Adiposity Traits in Mexican Americans. PLoS One 11: e0166263. [Medline] [CrossRef]

19. Lee, S.J., Kadambi, S., David, C., Cooper, A.D. and Choi, S.Y. 2004. Association of hepatic lipase with proteoglycans stimulates the production of proteoglycans in vivo and in vitro. J. Lipid Res. 45: 1266-1271. [Medline] [CrossRef]

20. Li, X., Catalina, F., Grundy, S.M. and Patel, S. 1996. Method to measure apolipoprotein B-48 and B-100 secretion rates in an individual mouse: evidence for a very rapid turnover of VLDL and preferential removal of B-48- relative to B100-containing lipoproteins. J. Lipid Res. 37: 210-220. [Medline]

21. Mahley, R.W. and Ji, Z.S. 1999. Remnant lipoprotein metabolism: key pathways involving cell-surface heparan sulfate proteoglycans and apolipoprotein E. J. Lipid Res. 40: 1-16. [Medline]

22. Mao, S.J., Rechtin, A.E. and Jackson, R.L. 1988. Monoclonal antibodies that distinguish between active and inactive forms of human postheparin plasma hepatic triglyceride lipase. J. Lipid Res. 29: 1023-1029. [Medline]

23. Medh, J.D., Bowen, S.L., Fry, G.L., Ruben, S., Andracki, M., Inoue, I., Lalouel, J.M., Strickland, D.K. and Chappell, D.A. 1996. Lipoprotein lipase binds to low density lipoprotein receptors and induces receptor-mediated catabolism of very low density lipoproteins in vitro. J. Biol. Chem. 271: 17073-17080. [Medline] [CrossRef]

24. Merkel, M., Kako, Y., Radner, H., Cho, I.S., Ramasamy, R., Brunzell, J.D., Goldberg, I.J. and Breslow, J.L. 1998. Catalytically inactive lipoprotein lipase expression in muscle of transgenic mice increases very low density lipoprotein uptake: direct evidence that lipoprotein lipase bridging occurs in vivo. Proc. Natl. Acad. Sci. USA 95: 13841-13846. [Medline] [CrossRef]

25. Murase, T. and Inoue, S. 1985. Hepatic triglyceride lipase is not an insulin-dependent enzyme in rats. Metabolism 34:
531-534. [Medline] [CrossRef]

26. Nakajima, K., Kobayashi, J., Mabuchi, H., Nakano, T., Tokita, Y., Nagamine, T., Imamura, S., Ai, M., Otokozawa, S. and Schaefer, E.F. 2010. Association of angiopoietin-like protein 3 with hepatic triglyceride lipase and lipoprotein lipase activities in human plasma. Ann. Clin. Biochem. 47: 423-431. [Medline] [CrossRef]

27. Nakajima, K., Machida, T., Imamura, S., Kawase, D., Miyashita, K., Fukamachi, I., Maeda, M., Muraba, Y., Koga, T., Kobayashi, J., Kimura, T., Nakajima, K. and Murakami, M. 2018. An automated method for measuring lipoprotein lipase and hepatic triglyceride lipase activities in post-heparin plasma. Clin. Chim. Acta 487: 54-59. [Medline] [CrossRef]

28. Nakajima, K. and Tanaka, A. 2018. Atherogenic postprandial remnant lipoproteins; VLDL remnants as a causal factor in atherosclerosis. Clin. Chim. Acta 478: 200-215. [Medline] [CrossRef]

29. Peterson, J., Bengtsson-Olivecrona, G. and Olivecrona, T. 1986. Mouse preheparin plasma contains high levels of hepatic lipase with low affinity for heparin. Biochim. Biophys. Acta 878: 65-70. [Medline] [CrossRef]

30. Phillips, M.S., Liu, Q., Hammond, H.A., Dugan, V., Hey, P.J., Caskey, C.J. and Hess, J.F. 1996. Leptin receptor missense mutation in the fatty Zucker rat. Nat. Genet. 13: 18-19. [Medline] [CrossRef]

31. Shimada, M., Ishibashi, S., Inaba, T., Yagyu, H., Harada, K., Osuga, J.I., Ohashi, K., Yazaki, Y. and Yamada, N. 1996. Suppression of diet-induced atherosclerosis in low density lipoprotein receptor knockout mice overexpressing lipoprotein lipase. Proc. Natl. Acad. Sci. USA 93: 7242-7246. [Medline] [CrossRef]

32. Shiomi, M., Ito, T., Yamada, S., Kawashima, S. and Fan, J. 2003. Development of an animal model for spontaneous myocardial infarction (WHHLMI rabbit). Arterioscler. Thromb. Vasc. Biol. 23: 1239-1244. [Medline] [CrossRef]

33. Su, X., Kong, Y. and Peng, D.Q. 2018. New insights into apolipoprotein A5 in controlling lipoprotein metabolism in obesity and the metabolic syndrome patients. Lipids Health Dis. 17: 174. [Medline] [CrossRef]

34. Takahashi, S. 2017. Triglyceride rich lipoprotein-LPLVLDL receptor and Lp(a)-VLDL receptor pathways for macrophage foam cell formation. J. Atheroscler. Thromb. 24: 552-559. [Medline] [CrossRef]

35. Taylor, J.M. and Fan, J. 1997. Transgenic rabbit models for the study of atherosclerosis. Front. Biosci. 2: d298-d308. [Medline] [CrossRef]

36. Wei, X., Wang, D., Yang, Y., Xia, M., Li, D., Li, G., Zhu, Y., Xiao, Y. and Ling, W. 2011. Cyanidin-3-O- $\beta$-glucoside improves obesity and triglyceride metabolism in KK-Ay mice by regulating lipoprotein lipase activity. J. Sci. Food Agric. 91: 1006-1013. [Medline] [CrossRef]

37. Zsigmond, E., Fuke, Y., Li, L., Kobayashi, K. and Chan, L. 1998. Resistance of chylomicron and VLDL remnants to post-heparin lipolysis in ApoE-deficient mice: the role of apoE in lipoprotein lipase-mediated lipolysis in vivo and in vitro. J. Lipid Res. 39: 1852-1861. [Medline] 